Dzwonkowski, B., Fournier, S., Reager, J. T., Milroy, S., Park, K., Shiller, A. M., Greer, A. T., Soto, I., Dykstra, S. L. and Sanial, V.: Tracking sea surface salinity and dissolved oxygen on a river-influenced, seasonally stratified shelf, Mississippi Bight, northern Gulf of Mexico, Continental Shelf Research, 169, 25-33, doi:10.1016/j.csr.2018.09.009, 2018.

Research papers

\title{
Tracking sea surface salinity and dissolved oxygen on a river-influenced, seasonally stratified shelf, Mississippi Bight, northern Gulf of Mexico
}

Brian Dzwonkowski ${ }^{\mathrm{a}, \mathrm{b}, *}$, Severine Fournier ${ }^{\mathrm{c}}$, John T. Reager ${ }^{\mathrm{c}}$, Scott Milroy ${ }^{\mathrm{d}}$, Kyeong Park ${ }^{\mathrm{e}}$, Alan M. Shiller ${ }^{\mathrm{d}}$, Adam T. Greer ${ }^{\mathrm{d}}$, Inia Soto ${ }^{\mathrm{d}, \mathrm{f}}$, Steven L. Dykstra ${ }^{\mathrm{a}, \mathrm{b}}$, Virginie Sanial $^{\mathrm{d}}$

a Department of Marine Sciences, University of South Alabama, Dauphin Island Sea Lab, Dauphin Island, AL 36528, USA

${ }^{\mathrm{b}}$ Dauphin Island Sea Lab, Dauphin Island, AL 36528, USA

c Jet Propulsion Laboratory, California Institute of Technology, Pasadena, CA 91109, USA

${ }^{\mathrm{d}}$ Division of Marine Science, University of Southern Mississippi, Stennis Space Center, MS 39529, USA

e Department of Marine Sciences, Texas A\&M University at Galveston, Galveston, TX 77553, USA

${ }^{\mathrm{f}}$ Harte Research Institute, Texas A\&M University at Corpus Christi, Corpus Christi, TX 78412, USA

\section{A R T I C L E I N F O}

\section{Keywords:}

Sea surface salinity

Region of freshwater influence

Hypoxia

Dissolved oxygen

Mississippi Bight

Gulf of Mexico

\begin{abstract}
A B S T R A C T
River discharge, and its resulting region of freshwater influence (ROFI) in the coastal ocean, has a critical influence on physical and biogeochemical processes in seasonally stratified shelf ecosystems. Multi-year (2010-2016) observations of satellite-derived sea surface salinity (SSS) and in situ water column hydrographic data during summer 2016 were used to investigate physical aspects of the ROFI east of the Mississippi River Delta to better assess regional susceptibility to hypoxia in the summer months. Time series of SSS data indicate that the shelf region impacted by the seasonal expansion of freshwater can be as extensive as the well-known "dead zone" region west of the Delta, and hydrographic observations from a shelf-wide survey indicate strong stratification associated with the ROFI. Peak buoyancy frequencies typically ranged between 0.15 and $0.25 \mathrm{~s}^{-1}$ and were concentrated in a 2-3 m layer around 4-10 m deep across much of the shelf. This ROFI is expected to be influenced by local freshwater sources which, while individually small, make a notable contribution in aggregate to the region (annually averaged daily discharge of approximately $2880 \mathrm{~m}^{3} \mathrm{~s}^{-1}$ ). The dissolved oxygen (DO) conditions under this freshwater cap were spatially and temporally variable, with areas of hypoxia and nearhypoxic conditions over portions of the shelf, demonstrating the utility of satellite-derived SSS in identifying coastal areas potential vulnerability to hypoxia. These regions of low bottom dissolved oxygen persisted throughout the peak summer season at several sites on the shelf, with the northeastern corner of Mississippi Bight having the most intense and persistent hypoxia.
\end{abstract}

\section{Introduction}

Shelf hypoxia (dissolved oxygen $<2 \mathrm{mgl}^{-1}$ ) is a well-recognized management issue for a growing number of coastal regions (Diaz and Rosenberg, 2008) that can alter food web dynamics and biogeochemical cycling, resulting in threats to fisheries, coastal economies, and ecosystem health (Breitburg et al., 2009; Diaz and Rosenberg, 2011). While hypoxia can occur naturally, the observed or predicted expansion of these conditions in different coastal systems has been linked to several anthropogenic causes, including changes in watershed land use and ocean warming (Rabalais et al., 2009; Bianchi et al., 2010; Dale et al., 2010; Breitburg et al., 2018). One well-studied region with regularly occurring hypoxia is the Louisiana Shelf in the northern Gulf of Mexico, the 2nd largest region of hypoxia globally (Rabalais et al., 2002a). This "dead zone", typically determined from an annual mid-summer shelf survey, is directly linked to river discharge through the delivery of nutrient-rich water from the Mississippi River watershed and the physical stratification that isolates the bottom water from the oxygenated upper layer (Rabalais et al., 1999; Dagg et al., 2007).

However, the influence of river discharge in the northern Gulf of Mexico extends well beyond the region typically measured by the annual summer survey. For example, a number of studies have demonstrated eastward spreading of Mississippi River water, which occurs episodically as a result of the passage of weather fronts, or more persistently during periods of southwest winds frequent in the summer season (Walker et al., 1994, 2005; Walker, 1996; Hitchcock et al., 1997; Morey et al., 2003a, 2003b; Schiller et al., 2011; Androulidakis and Kourafalou, 2013; Kourafalou and Androulidakis, 2013; Fournier

\footnotetext{
* Corresponding author.

E-mail address: briandz@disl.org (B. Dzwonkowski).
} 
et al., 2016). These studies typically highlight additional offshore factors, such as the position of the Loop Current and its associated eddies that can also impact the eastward transport of Mississippi River discharge. In fact, approximately $47 \%$ of the Mississippi River water exiting the bird-foot Delta is estimated to be delivered to the east and/or offshore (U.S. Army Corps of Engineers, 1974) as reported by Dinnel and Wiseman (1986). Additional eastward delivery of Mississippi River water can arise through anthropogenic intervention, such as the numerous spillways that can be opened to divert river water during flood events. The Bonnet Carré Spillway is particularly notable as this opening diverts river water east of the Delta directly into Lake Pontchartrain.

In addition to the direct impacts by the Mississippi River water, local sources of riverine water have the potential to contribute to shelf hypoxia in some coastal regions of the northern Gulf of Mexico. For example, the Mississippi Bight, a region of freshwater influence (ROFI) to the east of the Mississippi River Delta, receives river input from numerous local sources in Louisiana, Mississippi, Alabama, and West Florida (Table 1). While these local sources of river discharge are individually small, they cumulatively are equivalent to $\sim 44 \%$ of the Mississippi River discharge that is expected to travel eastward or offshore of the Mississippi River Delta, assuming 30\% of the Mississippi River discharge at Vicksburg, MS is diverted into the Atchafalaya River system (Nittrouer et al., 2012) and then $\sim 47 \%$ of the remaining discharge travel offshore or eastward (U.S. Army Corps Engineers, 1974).

The impact of high nutrient content and stratifying effects of Mississippi River discharge, as well as other contributing factors (e.g., sediment oxygen demand, grazing rates of microzooplankton) to the west the Mississippi River Delta, have been extensively examined (e.g., Turner and Rabalais, 1994; Justić et al., 2003, 2007; Rowe and Chapman, 2002; Scavia et al., 2003, 2004; Rabalais et al., 2007; Turner et al., 2007, 2012; Hetland and DiMarco, 2008; Lehrter et al., 2009; Liu et al., 2010; Fennel et al., 2011). However, the nutrient loading (one necessary component for development of hypoxia) associated with the local sources of freshwater in the Mississippi Bight is quite different than that of the Mississippi River discharge, which has a much higher nutrient content (Dunn, 1996). As a result, the hypoxia-related dynamics in the region to the east of the Delta have been poorly described relative to the adjacent system on the Texas-Louisiana Shelf. In fact, Bianchi et al. (2010) highlighted the frequency of occurrence and spatial extent of hypoxia east of the Mississippi River Delta as an open question in their review of hypoxia dynamics in the northern Gulf of

Table 1

The contribution of local rivers feeding into the Mississippi Sound and Bight relative to the Mississippi River discharge. The river data is derived from U.S. Geological Survey (USGS) stations between the Mississippi River Delta in the west and $86.5^{\circ} \mathrm{W}$ longitude to the east that had a minimum of $1 \mathrm{~m}^{3} \mathrm{~s}$ ${ }^{1}$ and 4 complete years of discharge. The station \# is the USGS station number. Discharge represents the annually (Oct-Sep) averaged daily discharge at each station and the \# of years is the number of years associated with the average.

\begin{tabular}{|c|c|c|c|}
\hline Station name & USGS station \# & \# of years & Discharge $\left(\mathrm{m}^{3} \mathrm{~s}^{-1}\right)$ \\
\hline Mississippi River at Vicksburg, MS & 7289000 & 7 & 19,854 \\
\hline Lake Pontchartrain $\left({ }^{\mathrm{LP}}\right)$ & & & 109 \\
\hline Amite River near Denham Springs, LA LP, LM & 7378500 & 78 & 59 \\
\hline Tickfaw River at Holden, LA LP, LM & 7376000 & 74 & 11 \\
\hline Natalbany River at Baptist, LA LP, LM & 7376500 & 72 & 3 \\
\hline Tangipahoa River at Robert, LA LP & 7375500 & 77 & 32 \\
\hline Tchefuncte River near Folsom, LA LP & 7375000 & 71 & 4 \\
\hline Pearl River $\left({ }^{\mathrm{PR}}\right)$ & & & 338 \\
\hline Pearl River near Bogalusa, LA ${ }^{\mathrm{PR}}$ & 2489500 & 78 & 282 \\
\hline Bogue Chitto River near Bush, LA ${ }^{\text {PR }}$ & 2492000 & 80 & 56 \\
\hline Bay St. Louis $\left({ }^{\mathrm{BL}}\right)$ & & & 24 \\
\hline Catahoula Creek near Santa Rosa, MS BL & 2481570 & 4 & 7 \\
\hline Wolf River near Landon, MS ${ }^{\mathrm{BL}}$ & 2481510 & 46 & 17 \\
\hline Biloxi Bay $\left({ }^{\mathrm{BB}}\right)$ & & & 10 \\
\hline Biloxi River at Wortham, MS ${ }^{\text {вв }}$ & 2481000 & 63 & 5 \\
\hline Tuxachanie Creek near Biloxi, MS ${ }^{\text {вв }}$ & 2480500 & 19 & 5 \\
\hline Pascagoula River (Pas) & & & 357 \\
\hline Pascagoula River at Graham Ferry, MS Pas & 2479310 & 15 & 326 \\
\hline Escatawpa near Agricola. MS Pas & 2479560 & 44 & 31 \\
\hline Mobile Bay $\left({ }^{\mathrm{MB}}\right)$ & & & 1726 \\
\hline Tombigbee River at Coffeeville Lock and Dam near Coffeeville, AL MB & 2469761 & 55 & 825 \\
\hline Alabama River at Claiborne Lock and Dam near Monroeville, AL $M B$ & 2428400 & 41 & 865 \\
\hline Chickasaw Creek near Kushla, AL MB & 2471001 & 65 & 8 \\
\hline Fowl River at Half-mile Rd near Laurendine, $\mathrm{AL}$ MB & 2471078 & 19 & 1 \\
\hline Bassett Creek at Walker Springs, AL MB & 2470100 & 14 & 7 \\
\hline Big Flat Creek near Fountain, AL MB & 2428500 & 27 & 8 \\
\hline Limestone Creek near Monroeville, $\mathrm{AL}_{\mathrm{MB}}^{\mathrm{MB}}$ & 2429000 & 18 & 4 \\
\hline Little River near Uriah, $\mathrm{AL}$ MB & 2429595 & 11 & 5 \\
\hline Fish River near Silver Hill, $\mathrm{AL}$ MB & 2378500 & 44 & 3 \\
\hline Perdido Bay $\left({ }^{\text {Per }}\right)$ & & & 37 \\
\hline Styx River near Elsanor, $\mathrm{AL}^{\text {Per }}$ & 2377570 & 40 & 12 \\
\hline Perdido River at Barrineau Park, FL Per & 2376500 & 76 & 22 \\
\hline Eleven Mile Creek near Pensacola, FL Per & 2376115 & 30 & 3 \\
\hline Pensacola Bay Pen $^{\text {Pen }}$ & & & 276 \\
\hline Escambia River near Molino, FL Pen & 2376033 & 27 & 184 \\
\hline Pond Creek near Milton, FL ${ }^{\text {Pen }}$ & 2370700 & 25 & 2 \\
\hline Big Coldwater Creek near Milton, FL ${ }^{\text {Pen }}$ & 2370500 & 68 & 15 \\
\hline Big Juniper Creek near Munson, FL Pen & 2370200 & 8 & 2 \\
\hline Blackwater River near Baker. FL Pen & 2370000 & 63 & 10 \\
\hline Yellow River near Milton, FL Pen & 2369600 & 15 & 63 \\
\hline
\end{tabular}

The superscripts associated with each gaging station indicate the primary river/estuary they contribute to: ${ }^{\mathrm{LP}}$ is Lake Pontchartrain, ${ }^{\mathrm{PR}}$ is the Pearl River, ${ }^{\mathrm{BS}}$ is Bay St. Louis, ${ }^{\mathrm{BB}}$ is Bay of Biloxi, ${ }^{\text {Pas }}$ is Pascagoula River, ${ }^{\mathrm{MB}}$ is Mobile Bay, ${ }^{\text {Per }}$ is Perdido Bay, and ${ }^{\text {Pen }}$ is Pensacola Bay. Note ${ }^{\mathrm{LM}}$ indicates the rivers that contribute to Lake Maruepas which in turn feeds into Lake Pontchartrain. 

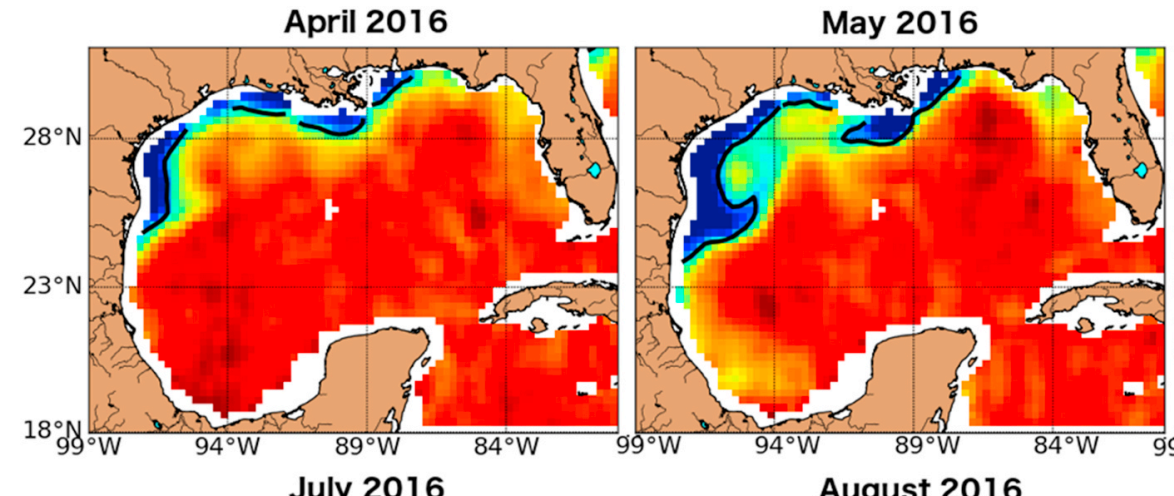

May 2016
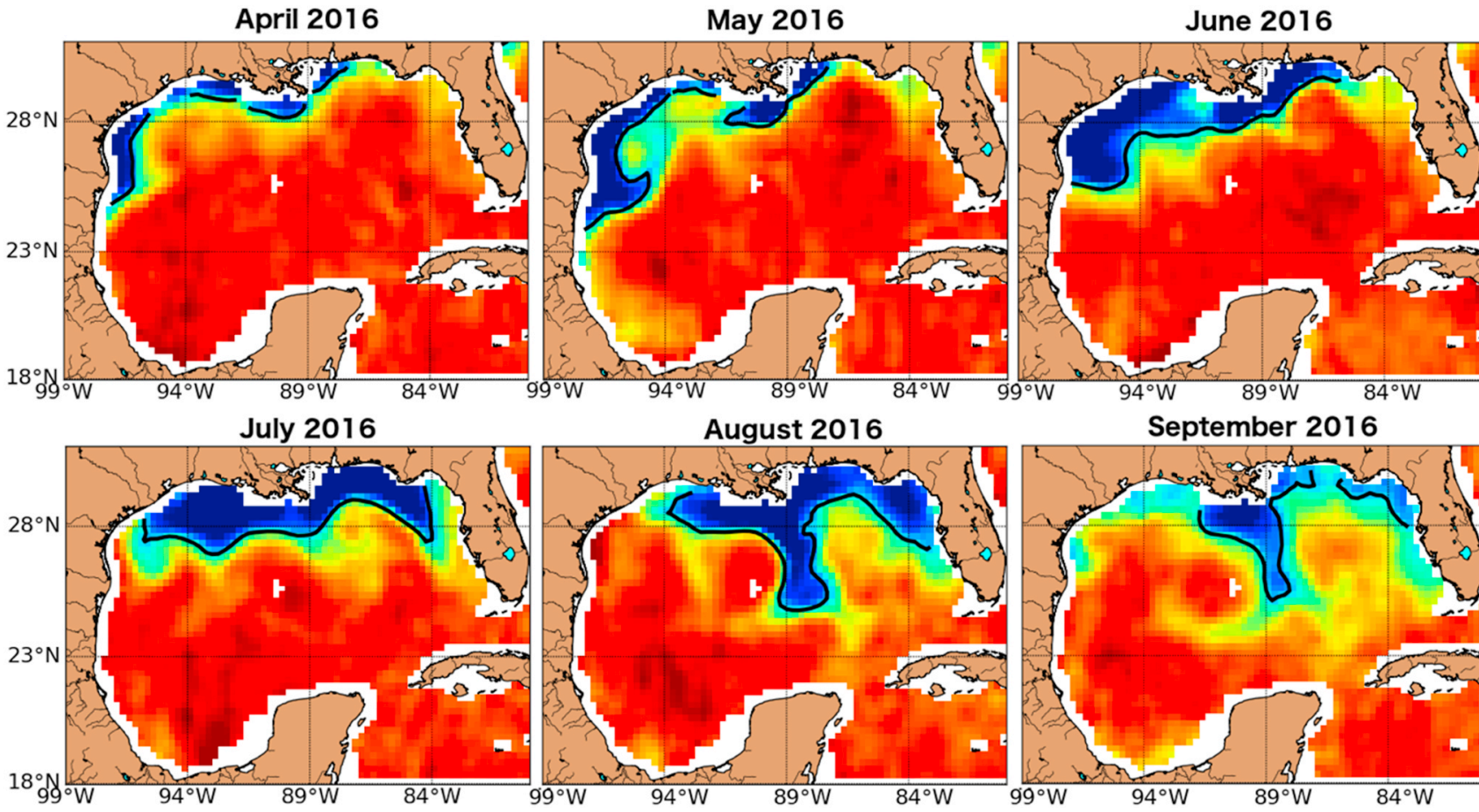

16

September 2016

Fig. 1. Spatial structure of the ROFI in the Gulf of Mexico. Sequence of satellite images from SMOS sensor ( $1 / 4^{\circ}$ resolution) for sea surface salinity (SSS) showing the

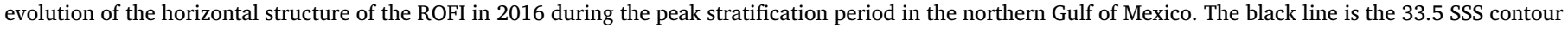

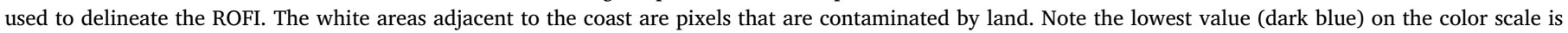
saturated to better highlight the spatial structure in the SSS.

Mexico. The western emphasis of hypoxia has significant policy implications as the most recent hypoxia area reduction plan put forth by the EPA Hypoxia Task Force is based on estimates that do not consider conditions in the Mississippi Bight (US EPA, 2008, 2013; Scavia et al., 2017).

To address the need for improved information on the ROFI and associated dissolved oxygen (DO) conditions east of the Mississippi River Delta, this study examines the evolution of surface salinity in the northern Gulf of Mexico and aspects of the DO characteristics in the Mississippi Bight. The development of hypoxic zones results from a combination of respiration depleting DO and physical processes (such as the combination of freshwater and solar heating induced stratification) limiting the equilibration of oxygen with the atmosphere. While both the physical and biogeochemical components of hypoxia are critical, we focus on the physical aspects of this balance in shelf waters of the northern Gulf of Mexico with the broader goal of improving the understanding of drivers contributing to the spatial and temporal patterns of DO in ROFIs, critical ecosystems in the coastal ocean. Specifically, this work highlights the extensive area impacted by freshwater discharge east of the Mississippi River Delta, which is on par with the region to the west of the Delta and demonstrates that satellitederived SSS is a useful tool in targeting coastal areas that are potentially vulnerable to hypoxia. While the available in situ DO data are temporally and spatially limited, there are areas of hypoxia and near-hypoxic conditions in the Mississippi Bight during the stratified season, which highlights the need for this shelf region to be considered in developing future management strategies for the northern Gulf of Mexico.

\section{Methods}

\subsection{Satellite data}

For delineating and tracking the evolution of patterns associated with the ROFI in the northern Gulf of Mexico, sea surface salinity (SSS) data were obtained from the European Space Agency (ESA) Soil
Moisture Ocean Salinity (SMOS) Earth Explorer mission. The SMOS SSS product used is a level 3, 4-day composite on a $1 / 4^{\circ}$ grid (i.e., $25 \mathrm{~km}$ spatial resolution) for the 2010-2016 period. As a result of this coarse spatial resolution, pixels by the coast are frequently contaminated by land and are excluded from the analysis. These regions are represented by white areas in the SSS plots (Fig. 1). Boutin et al. (2016) showed that the precision of the monthly SMOS SSS measurements are on the order of 0.2 globally when compared with in situ data. Note that all salinity values (both satellite-derived and in situ) presented are based on the practical salinity scale. Additional details on the SSS product used in this study can be found in Boutin et al. (2018).

Time series of monthly averaged SSS maps in the Gulf of Mexico from 2010 to 2016 were produced by averaging the gridded L3 4-day composites. From these monthly maps, the ROFI in the northern Gulf of Mexico was delineated by using the 33.5 isohaline contour (Fig. 1). This contour likely indicates some moderate to high level of stratification over the continental shelf and is similar to the salinity contour of 33 and 34 used by Kourafalou and Androulidakis (2013) and Morey et al. (2003a), respectively. Using the 33.5 surface contour as a boundary, the ROFI was then divided into a region east and west of the Mississippi River Delta using the $89.5^{\circ} \mathrm{W}$ longitude line as this is near the eastward edge of the Mississippi River Delta. With the east/west boundary line and the 33.5 contour, coverage areas and mean SSS values within each of the east and west regions were determined. Other contour values and east/west boundary lines were examined but did not qualitatively change the results. Using the 7-yr time series of monthly coverage areas and average salinities for both the east and west regions, a monthly ensemble average was produced. The months of April-September are emphasized to provide some context around the peak stratified period in June-August.

The satellite-derived SSS data were complimented with high resolution satellite-derived ocean color data for July 2016, a time period when several field programs were being conducted (see Section 2.2). The optical complexity of coastal water can impact the accuracy of standard ocean color data products in deriving water properties, 


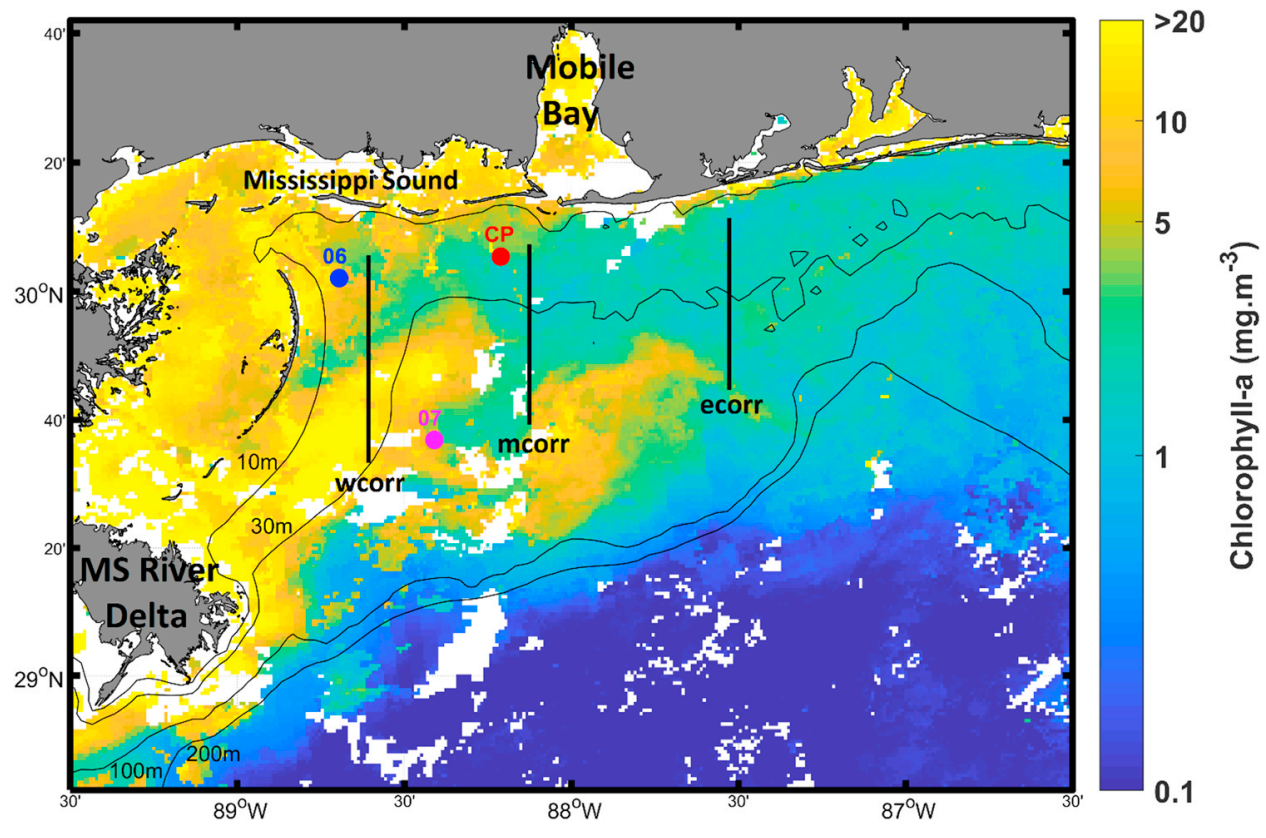

Fig. 2. Mississippi Bight region with the CONCORDE 2016 summer survey transects (labelled thick black lines) and selected times series locations of bottom dissolved oxygen (circles). Bathymetric contours highlight shelf structure (black lines). Coloration is 7-d average of chlorophyll-a derived from MODIS sensor ( $1 \mathrm{~km}$ resolution) for the week of July E 20-26, 2016. Due to the optical complexity of o) coastal waters, the chlorophyll-a concentration ह represents relative values but effectively illusTrates an intrusion of fresher water (yellow filament) on the shelf.

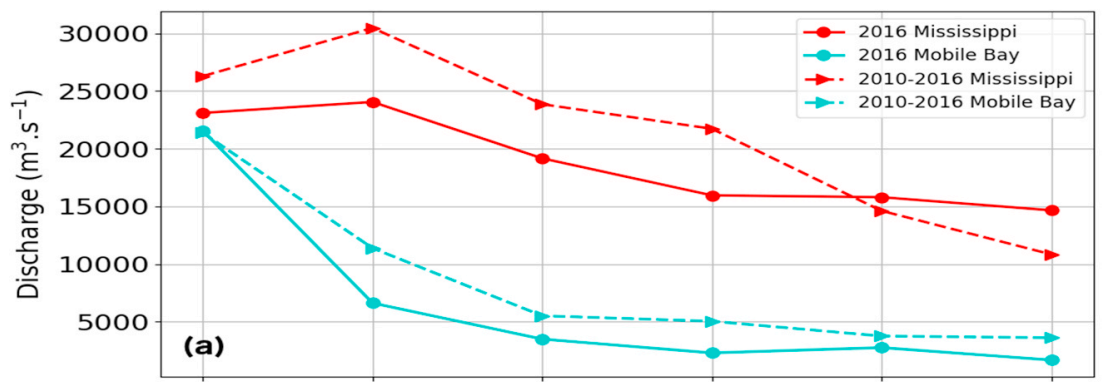

Fig. 3. Time series of the (a) river discharge for Mississippi River and Mobile Bay (scaled up by a factor of 8 ), and the (b) coverage area and (c) mean SSS in the ROFI to the east and west of the Mississippi River Delta: the monthly values in 2016 (solid lines) and the 7-yr ensemble averages (dashed lines) \pm 1 standard deviation (shaded). The ROFI is defined by the region with the 33.5 SSS contour and the east and west regions are determined by the $89.5^{\circ} \mathrm{W}$ longitude, i.e., approximate location of the Mississippi River Delta.
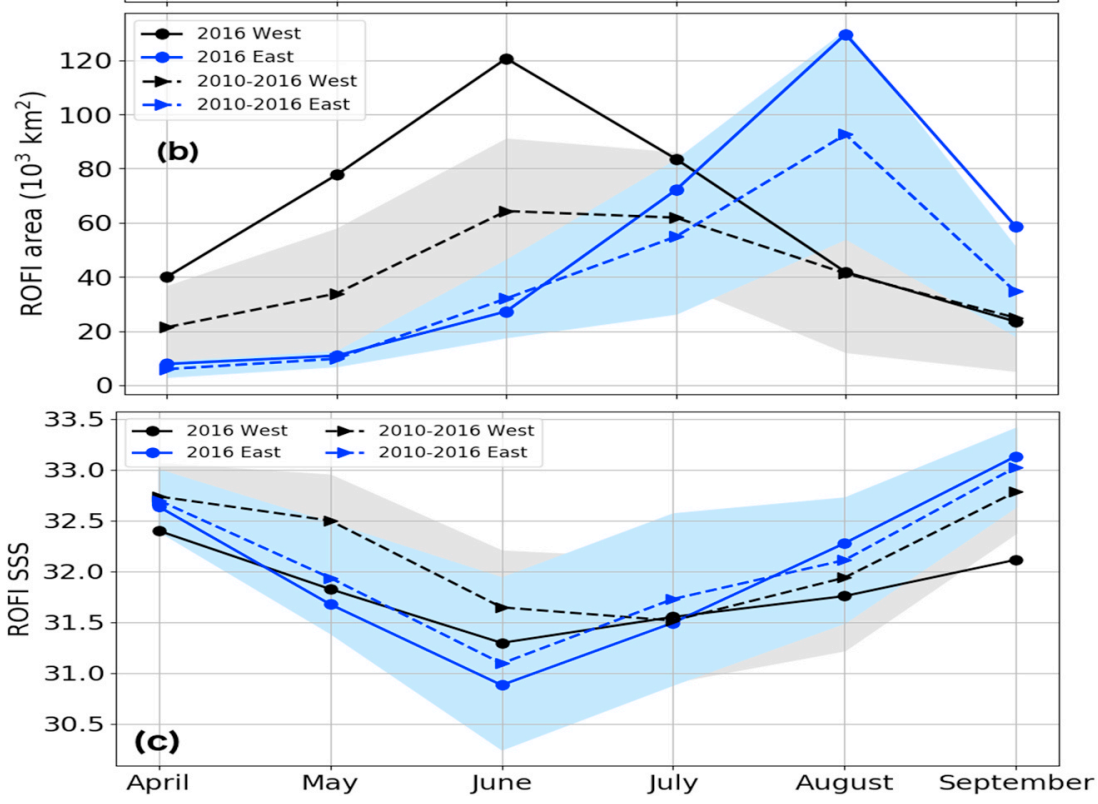

particularly in river-influenced systems where colored dissolved organic material and surface inorganic sediments can alter the water reflectance in the visible bands (e.g., D'Sa et al., 2006; Walker and Rabalais, 2006). However, many studies have qualitatively used 'chlorophyll-a' values from standard ocean color data products as a proxy for tracking river plumes (e.g., Dzwonkowski and Yan, 2005; Walker et al., 2005). For this study, AQUA/MODIS L2 chlorophyll-a data during July 20-26 2016 were mapped to a $1 \mathrm{~km}$ grid and used to provide a qualitative view of riverine/estuarine water relative to oceanic water during the hydrographic survey period.

\subsection{Field data}

To understand the hydrographic conditions associated with the 

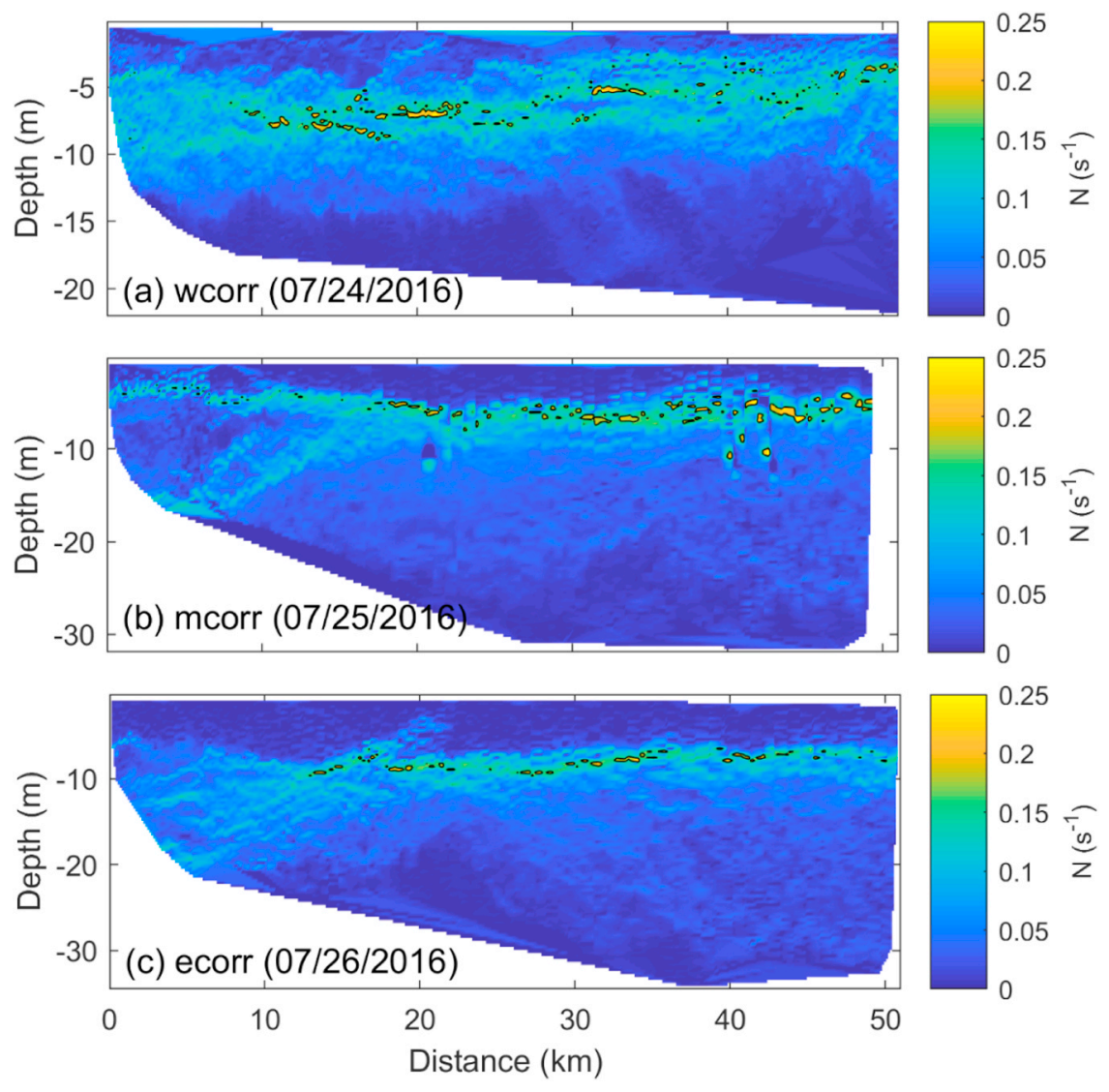

Fig. 4. Across-shelf transects of buoyancy frequency from the ISIIS towed CTD sensor for (a) wcorr, (b) mcorr, and (c) ecorr on July 24, July 25, and July 26, 2016, respectively (see Fig. 2 for locations of transects). The black contour highlights buoyancy frequencies above $0.17 \mathrm{~s}^{-1}$. Note the change in the y-axis in (b) and (c).

freshwater signal in the SSS data and the patterns of water column DO, field data from the CONsortium for oil spill exposure pathways in COastal RiverDominated Ecosytems (CONCORDE) program (Greer et al., 2018) and several near-bottom mounted DO sensors were obtained for the summer of 2016 (Fig. 2). The stratified season of 2016 was emphasized due to the enhanced sampling effort on the shelf during this period. Oceanographic surveys were conducted from the $R / V$ Point Sur along three $\sim 50 \mathrm{~km}$ northsouth lines during July 24-26, 2016. The measurements of temperature, salinity, density and DO were made between $\sim 2 \mathrm{~m}$ above the bottom and $\sim 2 \mathrm{~m}$ below the surface from a Conductivity-Temperature-Depth (CTD) system attached to the remotely operated towed vehicle known as the In Situ Ichthyoplankton Imaging System (ISIIS). The DO sensor on the ISIIS CTD system is a SeaBird Electronics (SBE) 43 and is expected to have an accuracy of $\pm 0.13 \mathrm{mg} \mathrm{l}^{-1}$. Detailed information for sampling and gridding ( $\Delta \mathrm{z}=0.2 \mathrm{~m}$ and $\Delta \mathrm{x}=200 \mathrm{~m}$ ) can be found in Dzwonkowski et al. (2017). It is important to note that the deepest ISIIS measurements occur approximately $1.5 \mathrm{~m}$ higher in the water column compared to the DO measurements obtained for the annual hypoxia survey conducted by the Hypoxia Research Team at the Louisiana Universities Marine Consortium (LUMCON: https//gulfhypoxia.net/). Additional hourly averaged high frequency near bottom DO data ( $\Delta t=2-15 \mathrm{~min})$ were obtained from several near bottom HОВО loggers (U26-001; Onset computer, Bourne, MA) deployed at various locations on the shelf (Fig. 2). The logger deployment depths were dependent on available subsurface structures and were generally at or near the bottom with FH06 being $\sim 1.2 \mathrm{~m}$ from the bottom in $21.2 \mathrm{~m}$ of water, FH07 being $\sim 6.0 \mathrm{~m}$ from the bottom in $41.1 \mathrm{~m}$ of water, and CP being $\sim 0.8 \mathrm{~m}$ from the bottom in $20.0 \mathrm{~m}$ of water. HOBO loggers were calibrated following manufacturer instructions including pre- and post-deployment assessments. In addition, the DO sensors were deployed with conductivity sensors so that salinity corrections could be made as recommended by the manufacturer, with the exception being site $\mathrm{CP}$, where the CTD sensor failed. However, a validation CTD cast during the sampling period at this site indicated good readings through August 3, 2016, after which data quality degraded. Based on the calibration practices associated with the HOBO loggers the expected error in the DO measurements is $\pm 0.2 \mathrm{mgl}^{-1}$. Daily discharge data were obtained for the Mississippi River at the USGS station at Vicksburg, MS and for the Mobile River system at two USGS stations for the Alabama River and Tombigbee River, which represent the vast majority of river water flowing into Mobile Bay (Table 1).

\section{Results}

\subsection{Horizontal extent of the ROFI}

SSS data for the stratified seasons from late spring to early fall showed the freshwater signal throughout the Gulf of Mexico (Fig. 1). As evidenced in the imagery, freshwater inputs to the northern Gulf of Mexico were present throughout the study period, and there was a significant freshening on the shelf relative to offshore across the entire northern Gulf of Mexico. The temporal and spatial evolution of the ROFI were quantified using the coverage area and mean SSS to characterize the relative impact of this feature to the east and west of the Mississippi River Delta (Fig. 3). The ROFIs to the east and west of the Mississippi River Delta expanded rapidly from April to mid/late summer in 2016, increasing from $40 \times 10^{3}$ to $120 \times 10^{3} \mathrm{~km}^{2}$ for the western region and $7 \times 10^{3}$ to $130 \times 10^{3} \mathrm{~km}^{2}$ for the eastern region. While the overall size of these regions was similar, the timing of the peak period was offset by two months, with the western (eastern) region peaking in June (August). Interestingly, the rates of expansion (i.e., the slope of the line from April to June for the western region and from June to August for the eastern region) were similar. Note that the phase lag in growth was not mirrored by enhanced river discharge from local sources. Mobile Bay, the largest local system delivering freshwater into 
the Mississippi Bight, peaked well before the August peak of the eastern ROFI, which suggests that advective processes may be important for the summer expansion of freshwater.

Mean SSS decreased in connection with increasing spatial coverage of freshwater discharge. Both regions had similar surface salinity beginning with values of $\sim 32.5$ in April and decreased to a summer minimum in June of $\sim 31$. The month of September had a particularly sharp decline in coverage area in the eastern region ( $\sim 54 \%$ reduction) and a notable increase in mean salinity (32.3-33.1). Overall, the ROFIs to the west and east of the Mississippi River Delta were similar in size and mean salinity during peak summer months (June-August) of 2016.

Considering the potential for large interannual variability, the stratified season in 2016 was compared to the 7-yr (2010-2016) ensemble averaged characteristics of the ROFI to evaluate whether the observed conditions in 2016 were representative of typical patterns on the shelf and adjacent waters. In terms of the coverage area and mean salinity, their time evolution in 2016 was similar to the ensemble averaged conditions in both regions. In both the western and eastern regions, the overall size and freshening were larger in 2016 when compared to the ensemble averages. In addition to placing the 2016 conditions within the context of long term patterns, the ensemble averaged characteristics highlighted the broader patterns of the two zones of the ROFI. Focusing on the peak summer months (JuneAugust), the mean characteristics were similar with mean coverage areas of $60( \pm 14) \times 10^{3} \mathrm{~km}^{2}$ (east) and $56( \pm 11) \times 10^{3} \mathrm{~km}^{2}$ (west), as well as mean salinities of $31.6( \pm 0.3)$ (east) and $31.6( \pm 0.2)$ (west). These results indicated that the size of the ROFI in the eastern region typically had a coverage area and mean SSS similar to those of the western region during the peak stratification period in June-August.

\subsection{Shelf stratification}

The vertical structure of the large ROFI to the east of the Mississippi
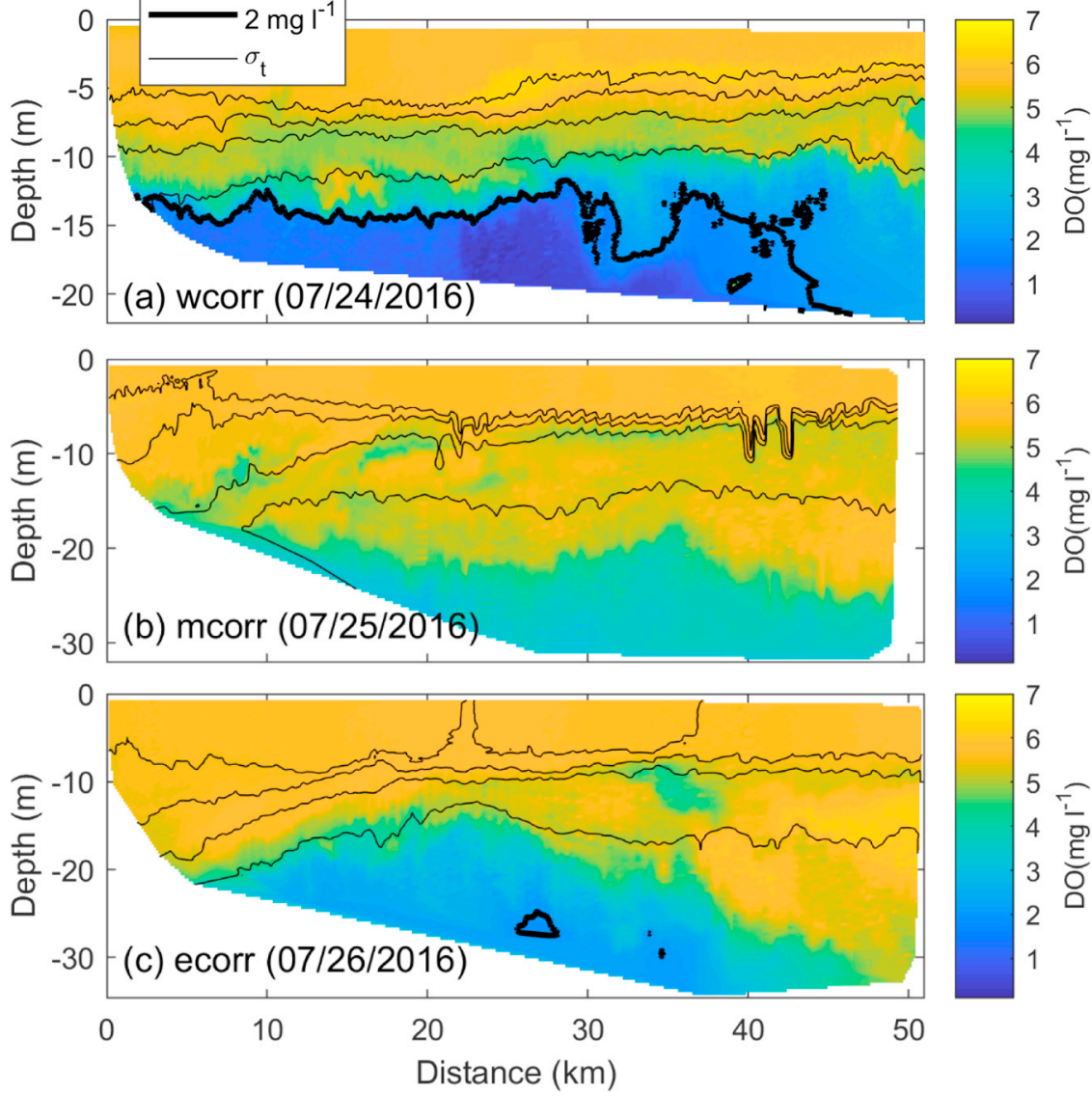
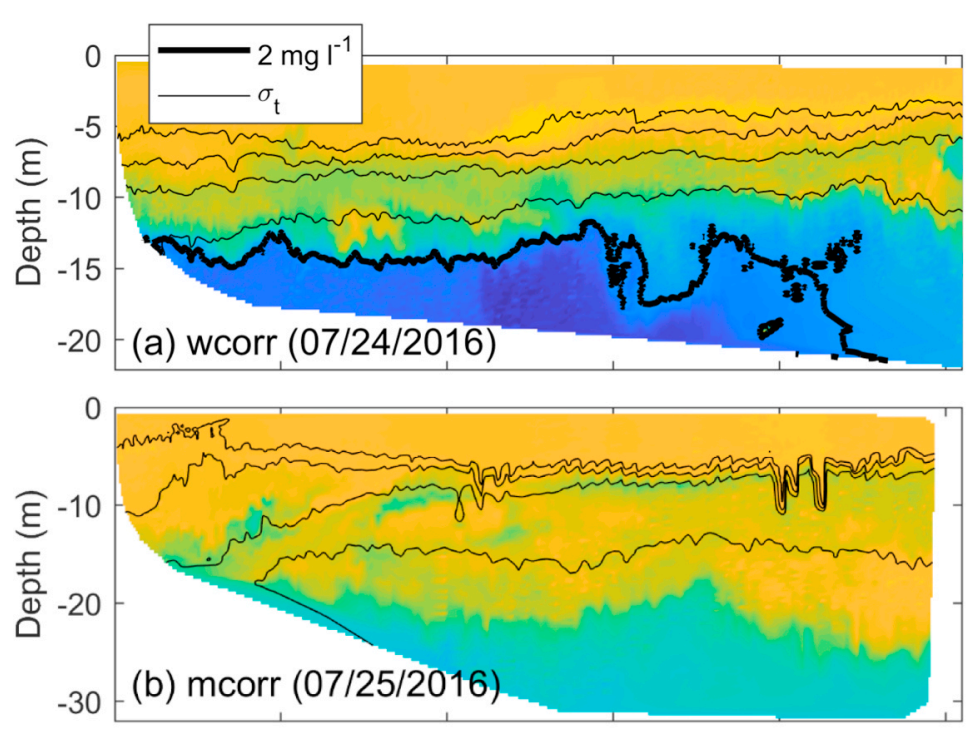

Distance $(\mathrm{km})$
River Delta was examined with data from the CONCORDE survey lines. In general, this region of the ROFI had a strong freshwater lens, with surface to bottom salinity differences typically on the order of 5-8 across the shelf. These salinity gradients, coupled with temperature gradients (See Supplemental Material), resulted in strong vertical density gradients (Fig. 4) with corresponding high buoyancy frequencies (N) (Fig. 4). Peak buoyancy frequencies typically ranged between 0.15 and $0.25 \mathrm{~s}^{-1}$ and were concentrated in a 2-3 $\mathrm{m}$ layer of the water column around 4-10 $\mathrm{m}$ deep across much of the shelf, except near the coast where the pycnocline broke down. The change in stratification near the coast resulted from a strong winddriven downwelling event (not shown) which modified the density structure tilting the isopycnals downward and offshore (i.e., Fig. 5b,c).

\subsection{Dissolved oxygen on the shelf}

While all three transects had generally high levels of stratification, the water column DO patterns varied spatially (Fig. 5). Clearly, wcorr had the lowest DO levels, with hypoxic conditions covering the majority of the bottom layer deeper than $\sim 13 \mathrm{~m}$. In contrast, the mcorr and ecorr transects were generally not hypoxic, although both transects still had low levels of DO with near-bottom values ranging from 2 to $3 \mathrm{mg} \mathrm{l}^{-1}$. Interestingly, ecorr had somewhat lower values than mcorr with various patches of near-bottom DO being at or just below $2 \mathrm{mgl}^{-1}$. The nearshore end of all the transects had elevated DO, relative to offshore locations, due to mixing and downward advection of surface waters from a downwelling event during the survey period. It is worth noting that the ISIIS instrument undulates throughout the water column staying of $\sim 2 \mathrm{~m}$ above the bottom so the DO level at the bottom may be lower than the values captured along the transect.

Time series data of DO (Fig. 6) were consistent with the spatial structure in the survey data. The site FH06 in the northwest corner of the Mississippi Bight generally had the most frequent and intense hypoxic periods. Waters in the eastern-most and southern-most sites (CP and FH07, respectively)
Fig. 5. Across-shelf transects of DO (coloration) and density (thin contours for the 18, 20, 22 and $24 \sigma_{t}$ levels) from the ISIIS towed CTD sensor for (a) wcorr, (b) mcorr, and (c) ecorr on July 24, July 25, and July 26, 2016, respectively (See Fig. 2 for locations of transects). In (a) and (c), the thick black lines are DO contours for $2 \mathrm{mg} \mathrm{l}^{-1}$. Note the change in the y-axis in (b) and (c). 


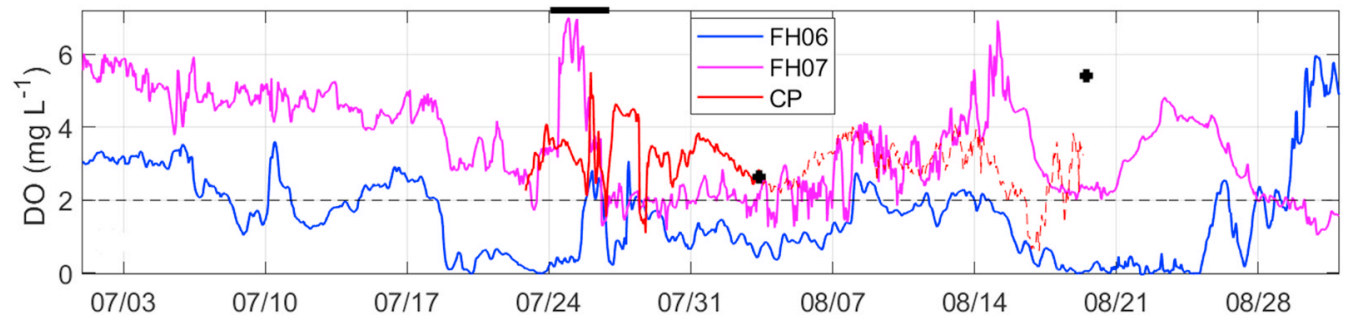

Fig. 6. Time series of DO at three sites: FH06, FH07 and CP (see Fig. 2 for locations). The horizontal black line at the top indicates the survey period and the black crosses are independent measurements of DO at site CP with the red dashed line showing the DO data with degraded data quality. Note that FH07 is $6 \mathrm{~m}$ above the bottom but still within the lower $15 \%$ of the water column. were generally not hypoxic, hovering between 2 and $4 \mathrm{mgl}^{-1}$ for long time periods ( $\sim 5-15$ day episodes). These observations were spatially consistent with the ship survey data. The fact the waters at the FH07 station were at or near hypoxic despite being $\sim 6.0 \mathrm{~m}$ off the bottom indicate there is a likely a thick layer of layer of low DO (and potential hypoxic values at the bottom) in this region of Mississippi Bight. The time series data also highlight the fact that the ship survey occurred during a period of elevated DO values, likely associated with the strong downwelling event. Rather than a straightforward trend of decreasing DO with distance from the Mississippi River Delta, the transects and time series data reveal more complex patterns.

\section{Discussion}

\subsection{Physical characterization of Mississippi Bight}

While the fine-scale details of the regional river plumes cannot be captured by the coarse resolution of the SMOS data, the imagery provides the broader structure and an indication of the intensity of the ROFI in the northern Gulf of Mexico. As might be expected from previous work in the northern Gulf of Mexico (e.g., Rabalais et al., 2002b), the SSS data in 2016 showed a broad region of low salinity water to the west of the Mississippi River Delta that expanded and intensified through the summer months. However, the SSS imagery clearly showed the region to the east of the Mississippi River Delta also had an expansive ROFI over the shelf. Physical processes associated with this freshwater expansion have been examined in previous studies (e.g., Walker et al., 1994; Weisberg, 1994; Morey et al., 2003a, 2003b; Schiller et al., 2011; Fournier et al., 2016); however, the multi-year record of satellite SSS provides a novel, spatially synoptic view of salinity characteristics of this region. The timing of the eastward expansion of fresher water and the associated time lag ( 2 months relative to the western ROFI in Fig. 3b) are consistent with the previous work mentioned above that linked the seasonal southwest winds with the eastward advection of Mississippi River water. In addition, freshwater from local sources in Louisiana, Mississippi, Alabama, and the Florida Panhandle would also be expected to be advected eastward as the seasonal inner/mid-shelf circulation is similarly eastward in the summer (Dzwonkowski and Park, 2010). Rather surprisingly, the ROFI coverage area and mean SSS to the east of the Mississippi River Delta are similar to those to the west of the Delta.

Combining satellite and in situ data during summer 2016 provides insight into the effects of this freshwater signal on shelf stratification and DO patterns. The available salinity and density data from within this ROFI showed a stratified water column with high buoyancy frequencies in the pycnocline, $\mathrm{O}\left(0.15 \mathrm{~s}^{-1}\right)$, across the shelf. While Belabbassi (2006) reported bottom hypoxia in the 'Dead Zone' region on the Texas-Louisiana shelf was associated with buoyancy frequency values greater $0.17 \mathrm{~s}^{-1}$, this was not always the case in the Mississippi Bight (Figs. 4 and 5). The transect data also highlighted important features in the spatial structure of the stratification on the shelf where a downwelling event, a typical summer phenomenon in this region (Dzwonkowski and Park, 2012), modified the nearshore density structure, likely oxygenating much of the nearshore region of the coast.

Given the relatively average levels of river discharge from the Mississippi River and Mobile Bay (Fig. 3a) as well as the lack of tropical storm activity during the summer 2016, the ship transects are likely representative of shelf hydrographic conditions in the Mississippi Bight. The observed stratification levels in 2016 are consistent with previous regional work of water column stability that have measured buoyancy frequencies on the order of 0.07-0.20 s-1 (Belabbassi, 2006; Dzwonkowski et al., 2018), similar to conditions observed on the Texas-Louisiana Shelf, i.e., buoyancy frequencies $\sim 0.07-0.28 \mathrm{~s}^{-1}$ (Wiseman et al., 1997; Belabbassi, 2006; Bianchi et al., 2010). However, the sources of the shelf stratification in the Mississippi Bight appear less straightforward. The Mississippi River discharge is much larger than the Mobile Bay discharge (Fig. 3a) and should be an important source of buoyancy on the shelf. In contrast, recent stable isotope work has indicated that local river sources, including the Mobile Bay discharge and smaller rivers in Mississippi, are the primary contributors of freshwater to the Mississippi Bight (Greer et al., 2018; Sanial et al., submitted). This suggest that the smaller local sources of river discharge might be more important to the physical structuring of inner to mid-shelf region than previously recognized, consistent with the findings of Greer et al. (2018).

\subsection{Biogeochemical implications for the Mississippi Bight}

Both the Mississippi Bight and Texas-Louisiana shelf have broad ROFIs with high levels of freshwater-derived stratification and limited physical mechanisms capable of enhancing vertical exchange between the surface and bottom waters during the summer months. This suggests the potential for large areas of shelf hypoxia to the east of the Mississippi River Delta. There are a few previous studies that focused on the hypoxia on the shallower regions of the Mississippi/Alabama shelf (e.g., Turner et al., 1987; Brunner et al., 2006; Milroy, 2016; Gunderson et al., in revision), but not much is known about the spatial extent or temporal duration/frequency of the hypoxic conditions over the entire Mississippi Bight. Moshogianis et al. (2013) provided a map for the spatial extent of hypoxia of about $2720 \mathrm{~km}^{2}$ in the Mississippi Bight in July 2011 but acknowledged that the actual hypoxic zone was most likely larger as the data collection did not extend past the Mississippi/Alabama border. Hypoxia was also observed in the Mississippi Bight during the 2011 annual hypoxia mapping conducted by LUMCON (https://gulfhypoxia.net/research/shelfwide-cruise/?y = 2011\& $\mathrm{p}=$ oxy_maps) whose sampling survey was atypically extended into this region. Greer et al. (2016) also reported hypoxia in the Mississippi Bight in 2011 to the east of River Delta (i.e., south of the wcorr transect). Rakocinski and Menke (2016) mapped the hypoxic zone in the summer of 2008 that was similarly limited by the spatial coverage of the survey. Jochens et al. (2002) provided some limited coverage across the Mississippi Bight but found no hypoxia on the shelf and only limited low DO on summer surveys during 1998-2000. In contrast, results presented here found areas of hypoxic/near-hypoxic conditions $\left(2.0-2.5 \mathrm{mg}^{-1}\right)$ on the shelf as far east as $87.53^{\circ} \mathrm{W}$, i.e., east of Mobile Bay mouth.

While the similar physical conditions are expected to provide the same potential for hypoxia, there might be considerable differences in the biogeochemical conditions between the ROFIs to the west and east of the Mississippi River Delta. The contribution of local rivers to the freshwater on the shelf is likely to be an important consideration, as the nutrient concentrations associated with these systems are much smaller than those in the Mississippi River (Dunn, 1996). Thus, if the Mississippi Bight indeed 
receives a lower supply of fluvial nutrients relative to the Louisiana Shelf, then either the Bight has a lower biogeochemical potential for hypoxia than the Louisiana Shelf, or the Bight has an additional source of allochthonous nutrients. For example, Montiel et al. (pers. comm.) highlight the importance of nutrient fluxes delivered to Mobile Bay by submarine groundwater discharge (SGD), which accounts for $51 \%$ of the total ammonium budget and $22 \%$ of the total nitrogen input during the low river flow regime, characteristic of the summer season. In other areas where hypoxia is directly connected to sewage treatment runoff, nutrient reductions have led to a coincident reduction in hypoxia, increased water clarity, and recovery of seagrass beds (Kemp et al., 2009; Greening et al., 2014; Staehr et al., 2017). However, some time series studies have shown nutrient reductions leading to biological community changes but no corresponding reduction in hypoxia, which can be attributed primarily to increasing stratification throughout the time series or changing rates of filtration (Kemp et al., 2009; Riemann et al., 2016). Clearly, the physical conditions have an impact on hypoxia intensity and coverage (Oviatt et al., 2017), especially in larger, more diffuse ROFIs (Kemp et al., 2009), but the details involving the interactions between the physical conditions, biological responses, and resulting hypoxia will remain important research topics in order to improve interannual predictability of hypoxia in ROFIs.

Another consideration is the episodic eastward advection of Mississippi River discharge, a typical summer phenomenon (e.g., Morey et al., 2003b), that contributes to the late summer expansion of the eastern ROFI. The role of this input on shelf hypoxia patterns in the Mississippi Bight has not been clearly determined. During the CONCORDE surveys, the wcorr transect had the largest area of hypoxia observed, but the near-bottom DO actually decreased in the direction of the Mississippi River Delta. In fact, the transect and time series data during 2016 suggest that the intensity and persistence of hypoxia decreased with distance away from the northwest corner of the Mississippi Bight, which is consistent with limited monitoring efforts across several programs and over a number of years (John Lopez and Stephan Howden, pers. comm.). However, there is likely significant interannual variability in the impact of Mississippi River water on the Mississippi Bight hypoxia patterns, as other previous work shows hypoxia closer to the Mississippi River Delta (e.g., Greer et al., 2016).

An additional consideration is the opening of the Bonnet Carre Spillway. While this is does not occur frequently, timing of the openings maybe important on the system hypoxia dynamics. During 2016, the Bonnet Carré Spillway was opened in January as a result of a large and relatively uncommon winter flooding event. Work by the CONCORDE program indicated much of the freshwater associated with this event was advected southward out of the Mississippi Bight region, consistent with the typically seasonal southwestward circulation patterns (Mustafa Kemal Cambazoglu, pers. comm.). However, potential biogeochemical impacts on summer hypoxia remains uncertain.

\section{Conclusions}

This study investigated relationships between river discharge, stratification, and DO patterns on a seasonally stratified shelf system, with a focus on water column properties in the ROFI east of the Mississippi River Delta. The satellite-derived SSS data provided evidence that the ROFI east of the Mississippi River Delta is similar in size and average salinity to the one west of the Mississippi River Delta. Local sources, while individually small, make a significant freshwater contribution in aggregate to the Mississippi Bight region (annually averaged daily discharge of approximately $2880 \mathrm{~m}^{3} \mathrm{~s}^{-1}$ ). While Mobile Bay is the largest contributor (approximately 60\%) to the collective total, several other riverine/estuarine systems are also notable including the Pascagoula River, Pearl River, Pensacola Bay, and Lake Pontchartrain.

With observations from in situ sampling programs in 2016, stratification and DO for a portion of the east ROFI were analyzed to characterize the temporal and spatial structure of the DO patterns. Despite strong stratification over much of the shelf, the ship surveys and time series data demonstrated variability in the horizontal and vertical structure of the DO patterns, with persistent hypoxia occurring in the northwest corner region of the Mississippi Bight and near-hypoxic waters widespread across the shelf during summer. Importantly, even though the eastern portion of the study region appears to be less hypoxic relative to the western portion of the Mississippi Bight and Texas-Louisiana shelf, the low DO levels observed, as well as the extensive ROFI that serves as a "cap" preventing deep waters from equilibrating with the atmosphere, suggest this region may be highly susceptible to becoming hypoxic should there be changes to background environmental conditions (e.g., increased ocean warming), regional watershed land use (e.g., coastal urbanization), or outflow pathways of freshwater discharge (e.g., increased discharge through spillways or erosional loss of the Mississippi River Delta). While the physical conditions in the east ROFI appear to be similar to those of the west ROFI, it is unclear whether the same biogeochemical processes may be at work. This raises broader questions about the factors impacting the oxygen budgets on the shelf and the relationships between freshwater-derived stratification, differing nutrient loads/sources, and biological interactions in river-influenced systems.

\section{Acknowledgements}

This work would not have been possible without the help of the Tech Support Group at the Dauphin Island Sea Lab and CONCORDE summer survey team. We thank Rich Pawlowicz at the University of British Columbia for the freely available MATLAB m_map toolbox. This research was made possible in part by a grant from The Gulf of Mexico Research Initiative, and in part by grants from the NASA SUSMAP program, Center for Environmental Resiliency at the University of South Alabama, NOAA Restore Science Program (NA17NOS4510101), and the National Fish and Wildlife Foundation. Data are publicly available through the Gulf of Mexico Research Initiative Information \& Data Cooperative (GRIIDC) at https:// data.gulfresearchinitiative.org (doi:10.7266/N75T3HXP, doi:10.7266/ N7QV3JXD). A portion of this work was conducted at the Jet Propulsion Laboratory, California Institute of Technology, under contract with NASA. We thank the NASA Goddard Space Flight Center, Ocean Ecology Laboratory, Ocean Biology Processing Group for the Moderate-resolution Imaging Spectroradiometer (MODIS) Aqua ocean color data; 2014 Reprocessing. NASA OB.DAAC, Greenbelt, MD, USA. doi:10.5067/AQUA/ MODIS/MODIS_OC.2014.0. Other data used for this manuscript are publicly available from various sources, including http://www.mymobilebay.com/ and the CNES-IFREMER CATDS for SMOS SSS data (http://www.catds.fr/).

\section{Appendix A. Supporting information}

Supplementary data associated with this article can be found in the online version at doi:10.1016/j.csr.2018.09.009.

\section{References}

Androulidakis, Y.S., Kourafalou, V.H., 2013. On the processes that influence the transport and fate of Mississippi waters under flooding outflow conditions. Ocean Dyn. 63 (2-3), 143-164.

Belabbassi, L., 2006. Examination of the relationship of river water to occurrences of bottom water with reduced oxygen concentrations in the northern Gulf of Mexico (Ph.D. Dissertation). Texas A\&M University, College Station, TX.

Bianchi, T.S., DiMarco, S.F., Cowan Jr, J.H., Hetland, R.D., Chapman, P., Day, J.W., Allison, M.A., 2010. The science of hypoxia in the Northern Gulf of Mexico: a review. Sci. Total Environ. 408 (7), 1471-1484.

Boutin, J., Martin, N., Kolodziejczyk, N., Reverdin, G., 2016. Interannual anomalies of SMOS sea surface salinity. Remote Sens. Environ. 180, 128-136.

Boutin, J., Vergely, J.-L., Marchand, S., D’Amico, F., Hasson, A., Kolodziejczyk, N., Reul, N., Reverdin, G., Vialard, J., 2018. New SMOS sea surface salinity with reduced systematic errors and improved variability. Remote Sens. Environ. 214, 115-134.

Breitburg, D., Hondorp, D.W., Davias, L.A., Diaz, R.J., 2009. Hypoxia, nitrogen, and fisheries: integrating effects across local and global landscapes. Annu. Rev. Mar. Sci. 1, 329-349.

Breitburg, D., et al., 2018. Declining oxygen in the global ocean and coastal waters. Science 359 (6371), 7240

Brunner, C.A., Beall, J.M., Bentley, S.J., Furukawa, Y., 2006. Hypoxia hotspots in the Mississippi Bight. J. Foraminifer. Res. 36 (2), 95-107.

Dagg, M.J., Ammerman, J.W., Amon, R.M.W., Gardner, W.S., Green, R.E., Lohrenz, S.E., 
2007. A review of water column processes influencing hypoxia in the northern Gulf of Mexico. Estuaries Coasts 30 (5), 735-752.

Dale, V.H., et al., 2010. Hypoxia in the Northern Gulf of Mexico. Springer, New York.

Diaz, R.J., Rosenberg, R., 2008. Spreading dead zones and consequences for marine ecosystems. Science 321 (5891), 926-929.

Diaz, R.J., Rosenberg, R., 2011. Introduction to environmental and economic consequences of hypoxia. Int. J. Water Resour. Dev. 27 (1), 71-82.

Dinnel, S.P., Wiseman Jr., W.J., 1986. Fresh water on the Louisiana and Texas shelf. Cont. Shelf Res. 6 (6), 765-784.

Dunn, D.E., 1996. Trends in Nutrient Inflows to the Gulf of Mexico from Streams Draining the Conterminous United States, 1972-93. Water-Resources Investigations Report 964113. U.S. Geological Survey.

D’Sa, E.J., Miller, R.L., Del Castillo, C., 2006. Bio-optical properties and ocean color al gorithms for coastal waters influenced by the Mississippi River during a cold front. Appl. Opt. 45 (28), 7410-7428.

Dzwonkowski, B., Yan, X.H., 2005. Tracking of a Chesapeake Bay estuarine outflow plume with satellite-based ocean color data. Cont. Shelf Res. 25 (16), 1942-1958.

Dzwonkowski, B., Park, K., 2010. Influence of wind stress and discharge on the mean and seasonal currents on the Alabama shelf of the northeastern Gulf of Mexico. J. Geophys. Res.: Oceans 115, C12052. https://doi.org/10.1029/2010JC006449.

Dzwonkowski, B., Park, K., 2012. Subtidal circulation on the Alabama shelf during the Deepwater Horizon oil spill. J. Geophys. Res.: Oceans 117, C03027. https://doi.org/ 10.1029/2011JC007664.

Dzwonkowski, B., et al., 2017. Estuarine influence on biogeochemical properties of the Alabama shelf during the fall season. Cont. Shelf Res. 140 (15), 96-109. https://doi. org/10.1016/j.csr.2017.05.001.

Dzwonkowski, B., Fournier, S., Park, K., Dykstra, S., Reager, J.T., 2018. Water column stability and the role of velocity shear on a seasonally stratified shelf, Mississippi Bight, Northern Gulf of Mexico. J. Geophys. Res.: Oceans 123. https://doi.org/10. 1029/2017JC013624.

US EPA, 2008. Gulf of Mexico Action Plan, 2008.〈https://www.epa.gov/ms-htf/gulfhypoxia-action-plan-2008>.

US EPA, 2013. Reassessment 2013: Assessing Progress Made Since 2008. 〈https://www. epa.gov/ms-htf/hypoxia-task-force-reassessment-2013-assessing-progress-made$2008>$.

Fennel, K., Hetland, R., Feng, Y., DiMarco, S., 2011. A coupled physical-biological model of the northern Gulf of Mexico shelf: model description, validation and analysis of phytoplankton variability. Biogeosciences 8, 1811-1899.

Fournier, S., Reager, J.T., Lee, T., Vazquez-Cuervo, J., David, C.H., Gierach, M.M., 2016. SMAP observes flooding from land to sea: the Texas event of 2015. Geophys. Res. Lett. 43 (19), 10338-10346.

Greening, H., Janicki, A., Sherwood, E.T., Pribble, R., Johansson, J.O.R., 2014. Ecosystem responses to long-term nutrient management in an urban estuary: Tampa Bay, Florida, USA. Estuar., Coast. Shelf Sci. 151, A1-A16.

Greer, A.T., Woodson, C.B., Smith, C.E., Guigand, C.M., Cowen, R.K., 2016. Examining mesozooplankton patch structure and its implications for trophic interactions in the northern Gulf of Mexico. J. Plankton Res. 38 (4), 1115-1134.

Greer, A.T., et al., 2018. Functioning of coastal river-dominated ecosystems and implications for oil spill response: from observations to mechanisms and models. Oceanography 31 (3). https://doi.org/10.5670/oceanog.2018.302.

Gunderson, K., Dillion, K., Howden, S., Martin, K., in revision. River discharge, stratification and shelf water hypoxia in the Mississippi Bight, Estuaries Coasts.

Hetland, R.D., DiMarco, S.F., 2008. How does the character of oxygen demand control the structure of hypoxia on the Texas-Louisiana continental shelf. J. Mar. Syst. 70 (1-2), 49-62.

Hitchcock, G.L., Wiseman Jr., W.J., Boicourt, W.C., Mariano, A.J., Walker, N., Nelsen, T.A., Ryan, E., 1997. Property fields in an effluent plume of the Mississippi River. J. Mar. Syst. 12, 109-126.

Jochens, A.E., DiMarco, S.F., Nowlin Jr., W.D., Reid, R.O., Kennicutt II., M.C., 2002. Northeastern Gulf of Mexico Chemical Oceanography and Hydrography Study: Synthesis Report. U.S. Department of the Interior, Minerals Management Service, Gulf of Mexico OCS Region, New Orleans, LA (OCS study MMS 2002-2055).

Justić, D., Rabalais, N.N., Turner, R.E., 2003. Simulated responses of the Gulf of Mexico hypoxia to variations in climate and anthropogenic nutrient loading. J. Mar. Syst. 42, $115-126$.

Justić, D., Bierman, V.J., Scavia, D., Hetland, R.D., 2007. Forecasting gulf's hypoxia: the next 50 years? Estuaries 30 (5), 791-801.

Kemp, W.M., Testa, J.M., Conley, D.J., Gilbert, D., Hagy, J.D., 2009. Temporal responses of coastal hypoxia to nutrient loading and physical controls. Biogeosciences 6, 2985-3008.

Kourafalou, V.H., Androulidakis, Y.S., 2013. Influence of Mississippi River induced circulation on the Deepwater Horizon oil spill transport. J. Geophys. Res.: Oceans 118 (8), 3823-3842.

Lehrter, J.C., Murrell, M.C., Kurtz, J.C., 2009. Interactions between freshwater input, light, and phytoplankton dynamics on the Louisiana continental shelf. Cont. Shelf Res. 29 (15), 1861-1872.

Liu, Y., Evans, M.A., Scavia, D., 2010. Gulf of Mexico hypoxia: exploring increasing sensitivity to nitrogen loads. Environ. Sci. Technol. 44 (15), 5836-5841.

Morey, S.L., Schroeder, W.W., O'Brien, J.J., Zavala-Hidalgo, J., 2003a. The annual cycle of riverine influence in the eastern Gulf of Mexico basin. Geophys. Res. Lett. 30 (16), 1867. https://doi.org/10.1029/2003GL017348.

Morey, S.L., Martin, P.J., O'Brien, J.J., Wallcraft, A.A., Zavala-Hidalgo, J., 2003b. Export pathways for river discharged fresh water in the northern Gulf of Mexico. J. Geophys. Res. 108 (C10), 3303. https://doi.org/10.1029/2002JC001674.

Milroy, S., 2016. Frequency of hypoxia at artificial reefs within the Mississippi Sound and Bight, Jun-Oct 2016. In Abstracts of the 2016 Bays and Bayous Symposium, Biloxi,
MS, Nov 30-Dec 1, 2016.

Moshogianis, A., Lopez, J., Henkel, T., Boyd, E., Baker, A., Hillmann, E., 2013. Preliminary Results of Recently Observed Hypoxia Development in the Chandeleur Sound and Breton Sound of Southeastern Louisiana, East of the Mississippi River Delta (Technical Report). Lake Pontchartrain Basin Foundation, New Orleans, LA.

Nittrouer, J.A., Shaw, J., Lamb, M.P., Mohrig, D., 2012. Spatial and temporal trends for water-flow velocity and bed-material sediment transport in the lower Mississippi River. Bull. Geol. Soc. Am. 124 (3-4), 400-414.

Oviatt, C., Smith, L., Krumholz, J., Coupland, C., Stoffel, H., Keller, A., McManus, M.C., Reed, L., 2017. Managed nutrient reduction impacts on nutrient concentrations, water clarity, primary production, and hypoxia in a north temperate estuary. Estuar., Coast. Shelf Sci. 199, 25-34.

Rabalais, N.N., Turner, R.E., Justić, D., Dortch, Q., Wiseman, W.J., 1999. Characterization of Hypoxia: Topic 1 Report for the Integrated Assessment on Hypoxia in the Gulf of Mexico. NOAA Coastal Ocean Program Decision Analysis Series No 15. Silver Spring, MD, pp. 167 (NOAA Coastal Ocean Program).

Rabalais, N.N., Turner, R.E., Wiseman Jr., W.J., 2002a. Gulf of Mexico hypoxia, aka "The dead zone". Annu. Rev. Ecol. Syst. 33 (1), 235-263.

Rabalais, N.N., Turner, R.E., Scavia, D., 2002b. Beyond science into policy: Gulf of Mexico hypoxia and the Mississippi River: nutrient policy development for the Mississippi River watershed reflects the accumulated scientific evidence that the increase in nitrogen loading is the primary factor in the worsening of hypoxia in the northern Gulf of Mexico. BioSci 52 (2), 129-142.

Rabalais, N.N., Turner, R.E., Sen Gupta, B.K., Boesch, D.F., Chapman, P., Murrell, M.C., 2007. Hypoxia in the northern Gulf of Mexico: does the science support the plan to reduce, mitigate, and control hypoxia? Estuaries Coasts 30 (5), 753-772.

Rabalais, N.N., Turner, R.E., Diaz, R.J., Justić, D., 2009. Global change and eutrophication of coastal waters. ICES J. Mar. Sci. 66 (7), 1528-1537.

Rakocinski, C.F., Menke, D.P., 2016. Seasonal hypoxia regulates macrobenthic function and structure in the Mississippi Bight. Mar. Pollut. Bull. 105 (1), 299-309.

Riemann, B., Carstensen, J., Dahl, K., Fossing, H., Hansen, J.W., Jakobsen, H.H., Josefson, A.B., Krause-Jensen, D., Markager, S., Staehr, P.A., Timmermann, K., Windolf, J., Andersen, J.H., 2016. Recovery of Danish coastal ecosystems after reductions in nutrient loading: a holistic ecosystem approach. Estuaries Coasts 39, 82-97.

Rowe, G.T., Chapman, P., 2002. Continental shelf hypoxia: some nagging questions. Gulf Mex. Sci. 20 (2), 153-160 (8).

Sanial, V., Shiller, A., Joung, D., Ho, P., 2018. Extent of Mississippi River water in the Mississippi Bight and Louisiana Shelf based on water isotopes. Estuar., Coast. Shelf Sci submitted for publication.

Scavia, D., Rabalais, N.N., Turner, R.E., Justić, D., Wiseman Jr., W.J., 2003. Predicting the response of Gulf of Mexico hypoxia to variations in Mississippi River nitrogen load. Limnol. Oceanogr. 48 (3), 951-956.

Scavia, D., Justić, D., Bierman Jr., V.J., 2004. Reducing hypoxia in the Gulf of Mexico: advice from three models. Estuaries 27 (3), 419-425.

Scavia, D., Bertani, I., Obenour, D.R., Turner, R.E., Forrest, D.R., Katin, A., 2017. Ensemble modeling informs hypoxia management in the northern Gulf of Mexico. Proc. Natl. Acad. Sci. USA 114 (33), 8823-8828.

Schiller, R.V., Kourafalou, V.H., Hogan, P., Walker, N.D., 2011. The dynamics of the Mississippi River plume: impact of topography, wind and offshore forcing on the fate of plume waters. J. Geophys. Res.: Oceans 116, C06029. https://doi.org/10.1029/ 2010JC006883.

Staehr, P.A., Testa, J., Carstensen, J., 2017. Decadal changes in water quality and net productivity of a shallow danish estuary following significant nutrient reductions. Estuaries Coasts 40, 63-79.

Turner, R.E., Schroeder, W.W., Wiseman, W.J., 1987. The role of stratification in the deoxygenation of Mobile Bay and adjacent shelf bottom waters. Estuaries Coasts 10 (1), 13-19.

Turner, R.E., Rabalais, N.N., 1994. Coastal eutrophication near the Mississippi river delta. Nature 368, 619-621.

Turner, R.E., Rabalais, N.N., Alexander, R.B., McIsaac, G., Howarth, R.W., 2007. Characterization of nutrient and organic carbon, and sediment loads and concentrations from the Mississippi River into the northern Gulf of Mexico. Estuaries Coasts 30, 773-790.

Turner, R.E., Rabalais, N.N., Justić, D., 2012. Predicting summer hypoxia in the northern Gulf of Mexico: redux. Mar. Pollut. Bull. 64, 319-324.

U.S. Army Corps of Engineers, 1974. Deep Draft Access to the Ports of New Orleans and Baton Rouge. Draft Environmental Statement, Corps of Engineers, New Orleans District.

Walker, N.D., Rouse Jr., L.J., Fargion, G.S., Biggs, D.C., 1994. The great flood of summer 1993: Mississippi River discharge studied. Eos Trans., AGU 75 (36), 409-415.

Walker, N.D., 1996. Satellite assessment of Mississippi River plume variability: causes and predictability. Remote Sens. Environ. 58 (1), 21-35.

Walker, N.D., Wiseman Jr., W.J., Rouse Jr., L.J., Babin, A., 2005. Effects of river discharge, wind stress and slope eddies on circulation and the satellite-observed struc ture of the Mississippi River plume. J. Coast. Res. 21, 1228-1244.

Walker, N.D., Rabalais, N.N., 2006. Relationships among satellite chlorophyll $a$, rive inputs and hypoxia on the Louisiana continental shelf, Gulf of Mexico. Estuaries Coasts 29 (6B), 1081-1093.

Weisberg, R.H., 1994. Transport of Mississippi River water to the west Florida shelf (Special Report) In: Dowgiallo, M.J. (Ed.), Coastal Oceanographic Effects of Summer 1993 Mississippi River Flooding. NOAA Coastal Ocean Office, pp. 55-59 (Special Report).

Wiseman, W.J., Rabalais, N.N., Turner, R.E., Dinnel, S.P., MacNaughton, A.N., 1997. Seasonal and interannual variability within the Louisiana coastal current: stratification and hypoxia. J. Mar. Syst. 12 (1-4), 237-248. 